\title{
REVIEW \\ Biological Aspects and Predatory Abilities of Hemipterans Attacking Stored-Product Insects
}

\author{
Taro IMAMURA*, Mika MURATA and Akihiro MIYANOSHITA \\ Food Safety Division, National Food Research Institute (Tsukuba, Ibaraki 305-8642, Japan)
}

\begin{abstract}
The subject of this study was to examine biological aspects and predatory abilities of predatory bugs that prey on stored-product insects. Biological controls in stored products are being regarded with increasing interest since they are nontoxic and do not damage human health or the environment. Several species of predatory bugs have been studied as biological control agents. Specifically, Xylocoris flavipes (Reuter) is the most studied candidate biological control agent among predatory bugs. X. flavipes is advantageous because it has a high population increase capacity and wide distribution. X. flavipes has been reported to suppress populations of small insects, but it can not predate large insects and internal grain feeding insects. As Amphibolus venator (Klug), Peregrinator biannulipes (Montrouzier \& Signoret) and Joppeicus paradoxus Puton can attack large insects, more research should be carried out on the suppression effects of these bugs. A combination of several biological control agents that can attack different types of insects will be needed to control whole pest complexes in various stored environments.
\end{abstract}

Disciplines: Insect pest / Postharvest technology

Additional key words: biological control, development, natural enemies, predatory bugs, suppression effect

\section{Introduction}

Methyl bromide $(\mathrm{MeBr})$ is one of the most useful chemical agents for pest control of stored products. Fumigation with $\mathrm{MeBr}$, however, may not be desirable from the standpoint of human health. More importantly, $\mathrm{MeBr}$ probably has ozone layer depleting effects, and for this reason was banned in most cases after 2005 in developed countries and will be banned after 2015 in developing counties. Therefore, the development of alternative methods and the switch to integrated pest management (IPM) are urgently needed. Biological control is thus being regarded with increasing interest, since it is nontoxic and does not damage human health or the environment. The use of natural enemies has been studied by various researchers for stored-product pests ${ }^{9}$.

In the past, several species of predatory bugs have shown good promise for suppressing populations of external feeding grain pests. Most of them belong to the family Anthocoridae. Among them, Xylocoris flavipes (Reuter) (Hemiptera: Anthocoridae) has been the most studied as a biological control agent ${ }^{9}$. This bug has already been commercialized in North America, and currently is the only predatory bug marketed for biocontrol of stored-product insects $^{20}$. Recently, we collected several predatory bugs belonging to the families Reduviidae and Joppeicidae. In this review, we introduce the biological aspects and predatory abilities of these predatory bugs, and consider their applicability as biological control agents.

\section{Biology of Predatory Bugs}

\section{Field investigation and species of predatory bugs}

Stored-product insects and their natural enemies were investigated in Thailand ${ }^{15}$ and tropical and subtropical regions of Japan (Okinawa-jima, Ishigaki-jima, Amami-oshima and Chichi-jima Islands) ${ }^{23,32,33}$. Table 1 shows the list of predatory bugs collected in these investigations. X. flavipes (Fig. 1A) was abundant in Thailand, but none were collected in $\operatorname{Japan}^{23,32,33,36}$, although it is known to be a cosmopolitan species ${ }^{15}$. X. flavipes is small in body size, so it preys on the eggs and smaller larvae of beetles and moths ${ }^{9}$. Amphibolus venator (Klug)

*Corresponding author: e-mail taroi@affrc.go.jp

Received 30 January 2007; accepted 17 April 2007. 
Table 1. Predatory bugs of stored-product insects collected in Thailand and tropical and subtropical regions of Japan

\begin{tabular}{|c|c|c|c|c|}
\hline Family & Species & Thailand $^{15}$ & Okinawa-jima $^{33}$ & Chichi-jima $^{32}$ \\
\hline \multirow[t]{7}{*}{ Anthocoridae } & Xylocoris flavipes (Reuter) & (a) & & \\
\hline & Xylocoris spp. & $\bigcirc$ & & \\
\hline & Cardiastethus pygmaeus Poppius & $\bigcirc$ & & \\
\hline & Amphiareus constrictus (Stål) & $\bigcirc$ & & \\
\hline & Physopleurella sp. & $\bigcirc$ & & \\
\hline & Dufouriellini gen. A. sp. & $\bigcirc$ & & \\
\hline & Dufouriellini gen. B. sp. & $\bigcirc$ & & \\
\hline \multirow[t]{3}{*}{ Reduviidae } & Amphibolus venator (Klug) & (a) & $\bigcirc$ & \\
\hline & Peregrinator biannulipes (Montrouzier \& Signoret) & (2) & $\bigcirc$ & \\
\hline & Vesbius purpureus (Thunberg) & $\bigcirc$ & & \\
\hline Joppeicidae & Joppeicus paradoxus Puton & (a) & & \\
\hline Lygaeidae & Clerada apicicornis (Erichson) & & & $\triangle$ \\
\hline Miridae & Fulvius anthocoroides (Reuter) & & & $\triangle$ \\
\hline
\end{tabular}

(O): Abundant, $\bigcirc$ : Occasionally, $\triangle$ : Few.

No predatory bug of stored-product insects was collected on Ishigaki-jima and Amami-oshima Islands in our investigation ${ }^{23,33}$.
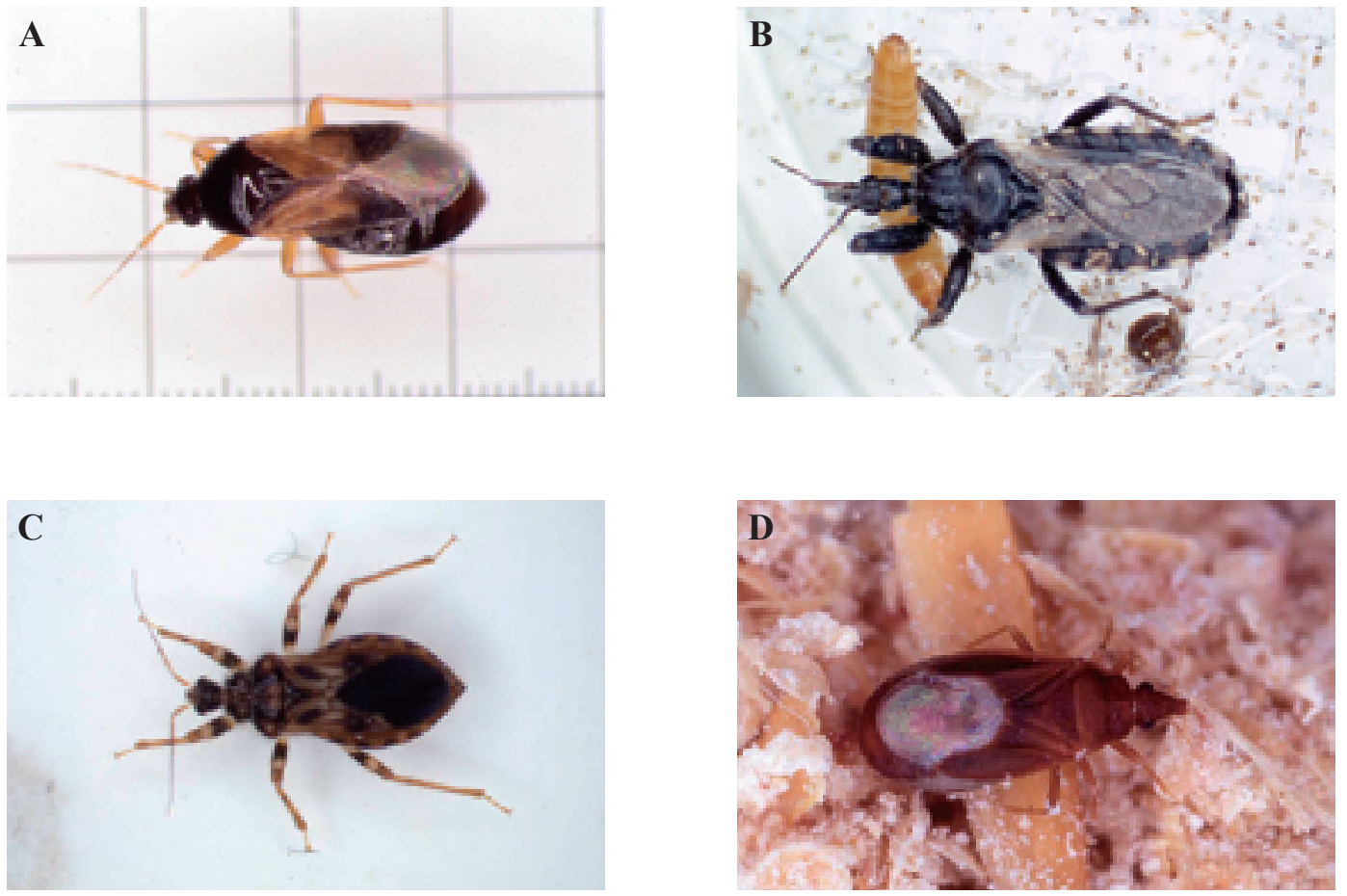

Fig. 1. Predatory bugs of stored product insects

(A): Xylocoris flavipes adult, about $2.1 \mathrm{~mm}$ long, (B): Amphibolus venator adult attacking Tribolium sp. larva, about $10 \mathrm{~mm}$ long, (C): Peregrinator biannulipes adult, about $7 \mathrm{~mm}$ long, (D): Joppeicus paradoxus adult in its habitat, about $3 \mathrm{~mm}$ long.

(Hemiptera: Reduviidae) (Fig. 1B) is a large bug, and was very common in rice stores in Thailand ${ }^{15}$. In Japan, it was found in rice milling facilities on Okinawa-jima Island $^{33}$. A. venator has also been reported in North
Africa, the Middle East and Malaysia ${ }^{15}$. This bug preys on various stored-product insects ${ }^{14,28}$, and in the rice milling facilities on Okinawa-jima Island, it is a major predatory insect ${ }^{33}$. Peregrinator biannulipes (Montrouzier \& 
Signoret) (Hemiptera: Reduviidae) (Fig. 1C) was commonly found in rice stores all over Thailand ${ }^{15}$ and in a rice milling facility on Okinawa-jima Island ${ }^{33}$. This bug has been found in pantropical regions ${ }^{15}$, and is known as a predator of various stored-product pests ${ }^{6,13,35}$. In Thailand and Palau, some individuals were collected from under the bark of trees ${ }^{34}$. Joppeicus paradoxus Puton (Hemiptera: Joppeicidae) (Fig. 1D) is the only member of the family Joppeicidae. It was collected from a bean store in northern Thailand ${ }^{15}$. J. paradoxus has been recorded in Egypt, Sudan, Ethiopia, and Israel, and its habitats have been reported to be sheltered situations, for example, under the bark of trees, among human and bat feces, in bat colonies, and on dusty and sandy ground ${ }^{31}$. It has also been found in warehouses and mills in Egypt ${ }^{1}$. Under laboratory conditions, J. paradoxus has been observed to feed on several insect species ${ }^{10,31}$.

As mentioned above, these four predatory bugs $(X$. flavipes, A. venator, P. biannulipes, and J. paradoxus) have already been reported as predators of stored-product insects, and are widely distributed in tropical and subtropical regions. Conversely, the other predatory bugs that were collected in our investigation (Table 1) were not so common. Therefore $X$. flavipes, $A$. venator, P. biannulipes, and $J$. paradoxus appear promising for biological control agents.

\section{Development times and life history parameters}

To determine the optimal rearing temperature for mass rearing and assess the suitability of the environmental conditions in the regions of the world where they are being evaluated as biological agents, information about the development times and life history parameters is needed.

Fig. 2 shows the development times of bugs known as predators of stored-product insects ${ }^{2-4,6,21,22,27}$. The development times of anthocorid bugs are generally shorter than those of reduviid bugs and $J$. paradoxus. In Dufouriellus ater (Dufour), Lyctocoris campestris (F.) (Hemiptera: Anthocoridae), A. venator and P. biannulipes, the development times decrease with increasing temperature, with the shortest development times observed at the highest temperature tested. In X. flavipes, the development time was the shortest at 30 and $35^{\circ} \mathrm{C}$, but immature mortality at $35^{\circ} \mathrm{C}$ was greatly higher than those at $25-30^{\circ} \mathrm{C}^{2}$. It appeared that $30^{\circ} \mathrm{C}$ was suitable for the immature development of $X$. flavipes. The development time of Xylocoris sordidus (Reuter) (Hemiptera: Anthocoridae) decreased with increasing temperature in the $20-35^{\circ} \mathrm{C}$ range, but immature development was inhibited at 15 and $40^{\circ} \mathrm{C}$, with neither egg hatch nor nymph molt observed at these temperatures ${ }^{3}$. The development time of $J$. paradoxus decreased with increasing temperature in the range of 25 to $30^{\circ} \mathrm{C}$. Immature mortality of $J$. paradoxus at $34^{\circ} \mathrm{C}$ was greatly higher than at $25-32^{\circ} \mathrm{C}$, indicating temperatures between 30 and $32^{\circ} \mathrm{C}$ are suitable for the immature development of this insect ${ }^{21}$.

The finite rate of natural increase $(\lambda)$ of predatory bugs is shown in Fig. $3^{2-4,17,21,25}$. The $\lambda$-values of $X$. flavipes, $X$. sordidus and L. campestris were generally higher than for the other species. The $\lambda$-values of $D$. ater were lower than for the other anthocorid bugs, although the development times of $D$. ater were similar to those of the other anthocorid bugs due to the lower daily egg production of this bug as compared with the other anthocorid bugs $^{4}$. The $\lambda$-values of $A$. venator and J. paradoxus were lower than for the other bugs due to their longer development times and lower fecundities ${ }^{17,21,22}$. In $X$. sordidus, $D$. ater and $A$. venator, the $\lambda$-values increased with increasing temperature for temperatures at and below $35^{\circ} \mathrm{C}$. This indicates that temperatures $\geq 35^{\circ} \mathrm{C}$ are suitable for increasing the population of these bugs. In $X$. sordidus, however, no adults emerged at $40^{\circ} \mathrm{C}^{3}$, indicating extremely high temperatures will have harmful effects on increasing the population of this bug. The $\lambda$-value of $X$. flavipes increased with increasing temperature in the range of $20-30^{\circ} \mathrm{C}$, and then decreased due to a higher immature mortality and lower fecundity at $35^{\circ} \mathrm{C}^{2}$. A similar trend was observed in $J$. paradoxus, for which the $\lambda$-value increased with increasing temperature to a peak at $30^{\circ} \mathrm{C}$ and then decreased. It

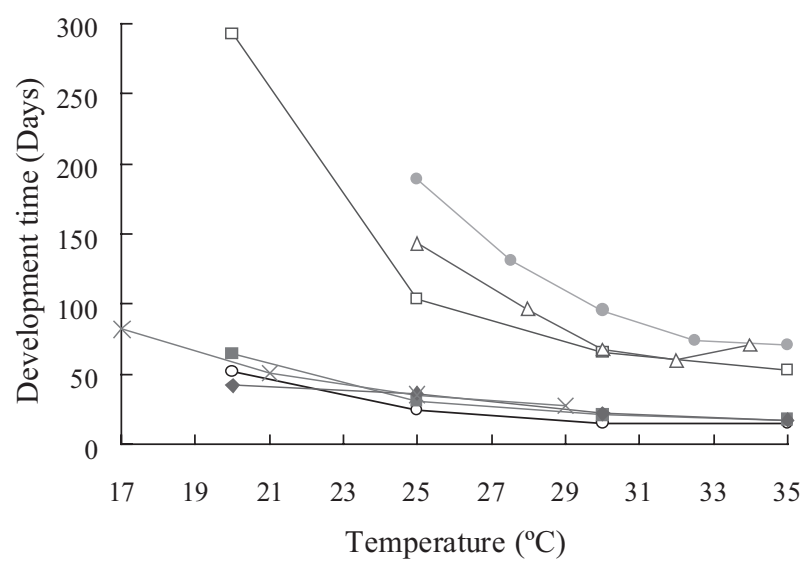

Fig. 2. Development times of predatory bugs

$-\infty$ : Xylocoris flavipes reared on Plodia interpunctella larvae ${ }^{2}$, - - Xylocoris sordidus reared on Cadra cautella larvae ${ }^{3},--$ : Dufouriellus ater reared on Plodia interpunctella larvae ${ }^{4},-\leftarrow$ : Lyctocoris campestris reared on Plodia interpunctella larvae ${ }^{27}, \rightarrow-:$ Amphibolus venator reared on Tribolium confusum larvae ${ }^{22},-\square-$ : Peregrinator biannulipes reared on Stegobium paniceum larvae ${ }^{6}$, $\triangle-$ : Joppeicus paradoxus reared on Tribolium confusum eggs ${ }^{21}$. 


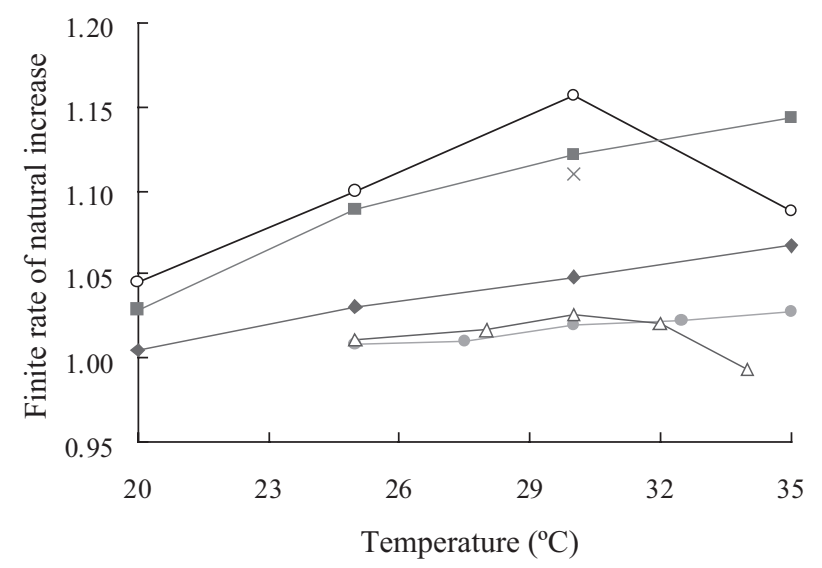

Fig 3. Finite rates of natural increase $(\lambda)$ of predatory bugs $-\circ$ : Xylocoris flavipes reared on Plodia interpunctella larvae ${ }^{2}, \rightarrow-:$ Xylocoris sordidus reared on Cadra cautella larvae ${ }^{3},-$ : Dufouriellus ater reared on Plodia interpunctella larvae ${ }^{4}, \quad \times$ : Lyctocoris campestris reared on Plodia interpunctella larvae ${ }^{25}, \rightarrow:$ : Amphibolus venator reared on Tribolium confusum larvae ${ }^{17},-\Delta_{-}:$Joppeicus paradoxus reared on Tribolium confusum eggs ${ }^{21}$.

appears that approximately $30^{\circ} \mathrm{C}$ is the optimal temperature for population increases of $X$. flavipes and J. paradoxus. Awadallah et al. ${ }^{6}$ reported the development and reproduction of $P$. biannulipes as a function of temperature. Considering its development time and fecundity, the $\lambda$-value of this bug would likely be lower than those of $X$. flavipes, $X$. sordidus and L. campestris, with its highest $\lambda$ value at $30^{\circ} \mathrm{C}$.

Temperatures $\geq 30^{\circ} \mathrm{C}$ seem to be suitable for the development and population increase of all of the bugs in this study except $L$. campestris, for which there is a lack of information on reproduction as a function of temperature. Among the bugs studied here, $X$. flavipes, $X$. sordi$d u s$ and L. campestris are suitable for mass rearing due to their high population increase capacities. However, it has been reported that $L$. campestris and P. biannulipes vary in their development times and fecundities according to the prey species ${ }^{6,25}$. More research on the optimal diet should be carried out to establish an easy method for rearing these bugs.

\section{Predatory Abilities and Suppression Effects}

\section{Predatory range and abilities}

There are some differences in the predatory ranges of bugs among bug species. Most of anthocorid bugs prey on the eggs and small larvae of stored-product moths and beetles. Brower et al. ${ }^{9}$ listed 17 species of Coleoptera and
6 species of Lepidoptera as prey of $X$. flavipes. As $L$. campestris is considerably larger than $X$. flavipes and other anthocorids, this bug preys on larger size prey than other anthocorid bugs. Parajulee \& Phillips ${ }^{25}$ listed 20 species of Coleoptera, 6 species of Lepidoptera and 2 species of Hymenoptera as prey of this bug. A. venator is larger than anthocorid bugs and also preys on larger prey. For example, it preys on adults of Tribolium spp. (Coleoptera: Tenebrionidae) ${ }^{24}$, which $X$. flavipes and $L$. campestris do not easily prey on. A comparison of the functional response to Tribolium spp. clearly shows the difference in the predatory abilities among $X$. flavipes, $L$. campestris and $A$. venator. It has been reported that a $X$. flavipes adult killed only 1 to 3 late-instar larvae of Tribolium castaneum (Herbst) in $24 \mathrm{~h}^{11}$. However, the maximum attack rate in $24 \mathrm{~h}$ of a $L$. campestris adult on the late-instar larvae of $T$. castaneum was estimated to be 5.0-11. $7^{26}$, and that of an A. venator adult on the lateinstar larvae of Tribolium confusum Jacquelin du Val was estimated to be 6.5-14.9 $9^{24}$. Furthermore, the maximum attack rate of an $A$. venator adult on $T$. confusum adults was estimated to be 3.6-27.8, revealing that $A$. venator is a good predator with regards to $T$. confusum adults ${ }^{24}$. It has been reported that $J$. paradoxus has a wide predatory range and kills the late-instar larvae and adults of $T$. confusum $^{10,18,31}$. This bug may be a good predator of larger prey.

\section{Suppression effects}

The suppression effects on stored-product insects have been investigated for several bug species ${ }^{9}$. X. flavipes is among the most studied bugs, with many studies regarding its suppression effects ${ }^{9}$. For example, Brower $\&$ Mullen $^{7}$ reported that releases of large numbers of $X$. flavipes suppressed Cadra cautella (Walker) and Plodia interpunctella (Hübner) (Lepidoptera: Pyralidae) populations in experimental peanut storages. However, the populations of stored grain pests infesting grain residues in empty corn bins were affected differently by the release of $X$. flavipes $^{8}$. In this test, the populations of small external feeding insects were greatly suppressed by the predator, but internal grain feeding insects such as Sitophilus spp. (Coleoptera: Curculionidae) and Rhyzopertha dominica (F.) (Coleoptera: Bostrichidae), and moths such as C. cautella and $P$. interpunctella were much less affected as compared with small external feeders such as Oryzaephilus surinamensis (L.) (Coleoptera: Silvanidae). This was attributed to the fact that internal feeding insects are protected in grain kernels, and $X$. flavipes has difficulty in attacking the large larvae and adults of pyralids. A combination of other biological control agents that can kill large or internal feeding pests is needed for this scenario. 
There have been a few reports on the suppression effects of the bugs that attack larger pests. Awadallah et al. ${ }^{5}$ examined the suppression effects of $P$. biannulipes on populations of Ephestia kuehniella (Zeller), Corcyra cephalonica (Stainton) (Lepidoptera: Pyralidae) and $T$. confusum, and reported their reduction rates to be $62.6 \%$, $59.8 \%$ and $95.5 \%$, respectively. The suppression effects of $A$. venator were also reported ${ }^{28}$. In a predator-treated warehouse, the populations of $C$. cautella and Alphitobius diaperinus (Panzer) (Coleoptera: Tenebrionidae) decreased $95.4 \%$ and $88.9 \%$ compared to the initial populations, respectively, while in the non-treated warehouse, these increased $197.8 \%$ and $161.5 \%$, respectively. Recently, Ishijima et al. ${ }^{18}$ conducted laboratory experiments to test the suppression effects of $X$. flavipes and another predatory bug $J$. paradoxus, whose adults can attack larger prey. The reduction rates of $T$. confusum populations with the release of $X$. flavipes and J. paradoxus were $97 \%$ and $67 \%$, respectively. In the $J$. paradoxus-treated groups, $T$. confusum adults were completely eliminated by $J$. paradoxus adults. However, when X. flavipes and J. paradoxus were released simultaneously, the reduction rate was only $35 \%$. This was attributed to $J$. paradoxus preying on $X$. flavipes as well as $T$. confusum. It is then necessary to find combinations of predators in which intraguild predation does not occur.

Intraguild predation has also been reported between $X$. flavipes and Bracon hebetor Say (Hymenoptera: Braconidae), which is a parasitoid of pyralid moth lar$v^{2}{ }^{29}$. The reduction rates of $P$. interpunctella with the release of $B$. hebetor and $X$. flavipes were $74 \%$ and $22 \%$, respectively. When $B$. hebetor and $X$. flavipes were released simultaneously, the reduction rate was $52.6 \%$. The number of $B$. hebetor was also reduced when $X$. flavipes was present, indicating that $X$. flavipes had fed on $B$. hebetor as well.

Combinations of predators of external feeding insects and parasitoids of internal feeding insects have yet to be tested. Pteromalid parasitoids such as Anisopteromalus calandrae (Howard), Lariophagus distinguendus (Förster) and Theocolax elegans (Westwood) (Hymenoptera: Pteromalidae) are expected to suppress populations of Sitophilus spp. and R. dominica ${ }^{12,16,30,37}$. More research is needed to suppress the entire pest complex in storage environments.

\section{Future Prospects}

$X$. flavipes is currently the most promising candidate as a biological control agent because of its high population increase capacity and wide distribution. However, this bug can not attack large pests, so more research is needed on the usage of other predatory bugs that can attack larger pests, like $A$. venator. Combinations of predators of external feeding insects and natural enemies of internal feeding insects should also be examined.

The rearing methods of the predatory bugs $X$. flavipes, A. venator, P. biannulipes, and $J$. paradoxus have been summarized by Ishijima et $\mathrm{al}^{19}$, and variations in the development times and fecundities according to the prey species have been reported ${ }^{6,25}$. It is important to find suitable prey for each predator to develop economically viable methods for mass rearing.

Biological control using predatory bugs is a component of integrated pest management strategies. To control whole pest complexes in various storage environments, this type of control will be used with other biological control agents such as parasitoids, pathogens and other types of predators. Further research on combinations with other control strategies such as sanitation, fumigation, irradiation, and packaging should also be carried out.

\section{Acknowledgments}

Our research on predatory bugs was partly carried out as a part of the project titled 'Development of lowinput technology for reducing postharvest losses of staples in Southeast Asia' of the Japan International Research Center for Agricultural Sciences.

\section{References}

1. Abdel-Rahman, H. A. et al. (1981) Survey and taxonomy of parasites and predators of stored grain and grain product insects. Bull. Soc. Entomol. Egypt, 61, 53-74.

2. Arbogast, R. T. (1975) Population growth of Xylocoris flavipes: influence of temperature and humidity. Environ. Entomol., 4, 825-831.

3. Arbogast, R. T., Flaherty, B. R. \& Press, J. W. (1983) Demography of the predaceous bug Xylocoris sordidus (Reuter). Am. Midl. Nat., 109, 398-405.

4. Arbogast, R. T. (1984) Demography of the predaceous bug Dufouriellus ater (Hemiptera: Anthocoridae). Environ. Entomol., 13, 990-994.

5. Awadallah, K. T., Tawfik, M. F. S. \& Abdellah, M. M. H. (1984) Suppression effect of the reduviid predator, Allaeocranum biannulipes (Montr. et Sign.) on populations of some stored-product insect pests. Z. Angew. Entomol., 97, 249-253.

6. Awadallah, K. T., Afifi, A. I. \& El-Sebaey, I. I. (1990) The biology of reduviid, Allaeocranum biannulipes (Mont. et Sign.), a predator of stored-product insect pests. Bull. Soc. Entomol. Egypt, 69, 169-181.

7. Brower, J. H. \& Mullen, M. A. (1990) Effect of Xylocoris flavipes (Hemiptera: Anthocoridae) releases on moth populations in experimental peanut storages. J. Entomol. Sci., 25, 268-276.

8. Brower, J. H. \& Press, J. W. (1992) Suppression of resid- 
ual populations of stored-product pests in empty corn bins by releasing the predator Xylocoris flavipes (Reuter). Biol. Control, 2, 66-72.

9. Brower, J. H. et al. (1996) Biological control. In Integrated management of insects in stored products, eds. Subramanyam, B. \& Hagstrum, D. W., Marcel Dekker Inc., New York, USA, 223-286.

10. Davis, N. T. \& Usinger, R. L. (1970) The biology and relationships of Joppeicidae (Heteroptera). Ann. Entomol. Soc. Am., 63, 577-587.

11. Donnelly, B. E. \& Phillips, T. W. (2001) Functional response of Xylocoris flavipes (Hemiptera; Anthocoridae): effects of prey species and habitat. Environ. Entomol., 30, 617-624.

12. Flinn, P. W. (1998) Temperature effects on efficacy of Choetospila elegans (Hymenoptera: Pteromalidae) to suppress Rhyzopertha dominica (Coleoptera: Bostrichidae) in stored wheat. J. Econ. Entomol., 91, 320-323.

13. Ghauri, M. S. K. (1962) Peregrinator kirkaldy (1904) (Reduviidae, Heteroptera) - a valid genus. Ann. Mag. Nat. Hist. Ser. 13, Zool. Bot. Geol., 5, 417-420.

14. Haines, C. P., ed. (1991) Insect and arachnids of tropical stored products: their biology and identification (a training manual), 2nd ed. Natural Resources Institute, Chatham, UK, pp.81.

15. Hayashi, T. et al., eds. (2004) Stored rice insect pests and their natural enemies in Thailand. JIRCAS International Agricultural Series No. 13, Funny Publishing Co. Ltd., Bangkok, Thailand, pp.79.

16. Imamura, T. et al. (2004) Effect of temperature on development of Theocolax elegans (Westwood) (Hymenoptera: Pteromalidae) parasitizing larvae of the maize weevil Sitophilus zeamais (Coleoptera: Curculionidae) in brown rice. Appl. Entomol. Zool., 39, 497-503.

17. Imamura, T. et al. (2006) Life history parameters of Amphibolus venator (Klug) (Hemiptera: Reduviidae), a predator of stored product insects. Rep. Natl. Food Res. Inst., 70, 19-22.

18. Ishijima, C. et al. (2005) Suppression effects of predatory bugs on the stored-product insect Tribolium confusum (Coleoptera: Tenebrionidae). Jpn. J. Appl. Entomol. Zool., 49, 143-145 [In Japanese with English summary].

19. Ishijima, C. et al. (2006) Biology and rearing methods of predatory bugs of stored-product insects. House Househ. Insect Pests, 27, 67-72 [In Japanese].

20. Mason, P. G. \& Huber, J. T., eds. (2001) Biological control programmes in Canada, 1981-2000. CABI Publishing, Wallingford, UK, pp.583.

21. Morimoto, S. et al. (2007) Effects of temperature on the development and reproduction of the predatory bug Joppeicus paradoxus Puton (Hemiptera: Joppeicidae) reared on Tribolium confusum eggs. Biol. Control, 40, 136-141.

22. Nishi, A. \& Takahashi, K. (2002) Effects of temperature on oviposition and development of Amphibolus venator (Klug) (Hemiptera: Reduviidae), a predator of stored product insects. Appl. Entomol. Zool., 37, 415-418.

23. Nishi, A., Takahashi, K. \& Nakamine, M. (2002) Storedproduct insects and their natural enemies at poultry farms and hoggeries in Amamioo-shima and Okinawa Islands,
Japan. Jpn. J. Environ. Entomol. Zool., 13, 49-57 [In Japanese with English summary].

24. Nishi, A. et al. (2004) Predatory abilities of Amphibolus venator (Klug) (Hemiptera: Reduviidae), a predator of stored-product insect pests. Appl. Entomol. Zool., 39, 321-326.

25. Parajulee, M. N. \& Phillips, T. W. (1993) Effects of prey species on development and reproduction of the predator Lyctocoris campestris (Heteroptera: Anthocoridae). Environ. Entomol., 22, 1035-1042.

26. Parajulee, M. N., Phillips, T. W. \& Hogg, D. B. (1994) Functional response of Lyctocoris campestris (F.) adults: effects of predator sex, prey species, and experimental habitat. Biol. Control, 4, 80-87.

27. Parajulee, M. N. et al. (1995) Life history of immature Lyctocoris campestris (Hemiptera: Anthocoridae): effects of constant temperatures and relative humidities. Environ. Entomol., 24, 889-897.

28. Pingale, S. V. (1954) Biological control of some stored grain pests by the use of a bug predator, Amphibolus venator Klug. Indian J. Ent., 16, 300-302.

29. Press, J. W., Flaherty, B. R. \& Arbogast, R. T. (1974) Interactions among Plodia interpunctella, Bracon hebetor, and Xylocoris flavipes. Environ. Entomol., 3, $183-184$.

30. Steidle, J. L. M. \& Schöller, M. (2002) Fecundity and ability of the parasitoid Lariophagus distinguendus (Hymenoptera: Pteromalidae) to find larvae of the granary weevil Sitophilus granarius (Coleoptera: Curculionidae) in bulk grain. J. Stored Prod. Res., 38, 43-53.

31. Štys, P. (1971) Distribution and habitats of Joppeicidae (Heteroptera). Acta. Faun. Ent. Mus. Nat. Prague, 14, 199-208.

32. Takahashi, K., Ohbayashi, T. \& Sota, N. (2000) Investigation of stored-product insect pests and their natural enemies in Chichijima Island, Ogasawara (Bonin), Japan. Jpn. J. Ent. (N.S.), 3, 97-103 [In Japanese with English summary].

33. Takahashi, K. \& Romero, M. V. (2001) Investigation of stored-product insect pests and their natural enemies in Okinawa-jima and Ishigaki-jima Islands, Okinawa, Japan. Jpn. J. Ent. (N.S.), 4, 91-97 [In Japanese with English summary].

34. Takahashi, K. \& Nishi, A. (2003) Habitat of Peregrinator biannulipes (Heteroptera; Reduviidae) in the field. Rostria, 51, 37-39 [In Japanese with English summary].

35. Tawfik, M. F. S., Awadallah, K. T. \& Abou-Zeid, N. A. (1983) The biology of the reduviid Allaeocranum biannulipes (Montr. et Sign.), a predator of stored-product insects. Bull. Soc. Entomol. Egypt, 64, 231-237.

36. Yasunaga, T., Takai, M. \& Kawasawa. T., eds. (2001) A field guide to Japanese bugs II - terrestrial heteropterans-. Zenkoku Noson Kyoiku Kyokai Publishing Co. Ltd., Tokyo, Japan, pp.360 [In Japanese].

37. Williams, R. N. \& Floyd, E. H. (1971) Effect of two parasites, Anisopteromalus calandrae and Choetospila elegans, upon populations of the maize weevil under laboratory and natural conditions. J. Econ. Entomol., 64, 1407-1408. 